\title{
İlkokullarda Okuma Güçlüğünde Kullanılan Eğitsel Uygulamalara İlişkin Öğretmen Algılarının İncelenmesi
}

\section{Ayfer Şahin iD 1}

Türkan BOZDAĞ

\footnotetext{
${ }^{1}$ Prof. Dr., Kırşehir Ahi Evran Üniversitesi, Eğitim Fakültesi, Sınıf Eğitimi Anabilim Dalı, e-mail:ayfersahin1@gmail.com

${ }^{27}$ Öğretmen, Milli Eğitim Bakanlı̆̆ı, e-mail:turkanbozdag4040@gmail.com
}

Anahtar Kelimeler

Okuma, alg1, okuma güçlüğü, eğitsel uygulamalar.

\section{Keywords}

Reading, perception, dyslexia, educational applications

\section{Sorumlu yazar/Corresponding Author \\ Türkan Bozdağ, Öğretmen, Milli Eğitim Bakanlığ 1 \\ Email: turkanbozdag4040@gmail.com}

Geliş/Received: 27.08 .2020

Kabul/Accepted: 25.11 .2020

\section{Öz}

$\mathrm{Bu}$ araştırmanın amacı, ilkokullarda okuma güçlüğünde kullanılan eğitsel uygulamalara ilişkin öğretmen algılarının cinsiyet, mesleki kıdem, öğretmenlerin okuttukları sınıf düzeyi, sınıflarında okuma güçlüğü yaşayan öğrencisi olma ve okuma güçlüğü ile ilgili herhangi bir kurs alma durumları değişkenlerine göre farkl1lık gösterip göstermediğini incelenmesidir. Araştırmada betimsel tarama modeli kullanılmıştır. Araştırmanın evrenini 2019-2020 eğitimöğretim yılında bir il ve ilçe merkezlerindeki ilkokullarda görev yapan sınıf öğretmenleri ile destek eğitim odasında görev yapan öğretmenler oluşturmaktadır. Araştırmada verilerin elde edilmesinde "Okuma Güçlüğ̈̈nde Kullanılan Eğitsel Uygulamalara İlişkin Öğretmen Alglları Ölçeğ (OGEUIAOO) " ile demografik bilgi formu kullanılmıştır. Toplam 173 öğretmen araştırmaya katılmıştır. Elde edilen veriler alt problemler dâhilinde SPSS paket programı ile analiz edilmiştir. Araştırma sonucunda ilkokullarda okuma güçlüğünde kullanılan eğitsel uygulamalara ilişkin öğretmen algılarının yüksek düzeyde olduğu belirlenmiştir. Öğretmen algılarının cinsiyete, kıdeme, okutulan sınıf düzeyine, sınıflarında okuma güçlüğü yaşayan öğrencisi olma durumuna, okuma güçlüğü ile ilgili herhangi bir kurs alma durumlarına göre farklılaşmadığı belirlenmiştir. Sınıf öğretmenleri ve destek eğitim odasında görev yapan öğretmenlere okuma güçlüğü yaşayan öğrencinin bireysel farklılığına göre farklı yöntem ve stratejilerle öğretim etkinliklerinin planlanması ve böylece okuma güçlüğü yaşayan öğrencileri daha iyi bir seviyeye getirmeleri yönünde ilgili makamlarca kurs, seminer vb. eğitimler düzenlenmesi önerilmiştir.

\section{Önerilen Atıf / Suggested Citation:}

Şahin, A. \& Bozdağ, T. (2020). İlkokullarda Okuma Güçlüğünde Kullanılan Eğitsel Uygulamalara İlişkin Öğretmen Algılarının İncelenmesi, Anadolu Kültürel Araştırmalar Dergisi, 4(3), 250-263 


\title{
Investigation of Teachers' Perceptions About Educational Practices Used in Reading Difficulties in Primary Schools
}

\begin{abstract}
The purpose of this study is to investigate whether teachers' perceptions towards educational applications used for dyslexia in the elementary schools differentiated for gender, tenure, class level taught by the teacher, having dyslexic students in the class and having dyslexia-related courses. This study used descriptive analysis method. The study universe consists of elementary school teachers and teachers working in the support education room in the 2019-2020 academic year in Kırşehir city centre and district centre elementary schools. For data collection purposes, this study uses "Teachers' Perception Towards Educational Applications Used in Dyslexia Scale (TPTEEAUDS)" and demographic information form. 173 teachers participate to this study. The obtained data is analysed with the SPSS package program by considering the sub-problems. As a result, this study shows that teachers' perceptions towards educational applications used for dyslexia in the elementary schools are at a high level. It is found that teachers' perception showed no difference for gender, tenure, class level, having dyslexic students in the class and having any dyslexia-related courses. It is recommended that classroom teachers' and teachers working in the support education room should plan curriculum activities with different methods and strategies depending on the individual differences of dyslexic students and in-service training such as courses, seminars etc. should be organised by authorised institutions o improve dyslexic students to a better level.
\end{abstract}

\section{GíRiș}

Günümüzde ilkokul çağındaki öğrencilerin okuma-yazmayı öğrenmeleri ile başlayan okuma, kâğıt üzerindeki birtakım şekillerin beyinde anlamlandırılması olarak ifade edilir. Aynı zamanda okuma, bu şekilleri görme, algılama ve kavrama süreci olarak da tanımlanır (Sidekli ve Yangın, 2005). Bu tanımlardan yola çıkarak okumanın zihinde gerçekleşen bir anlama süreci olduğu söylenebilir. Okuma; Özkara'ya (2010) göre ise sadece çözümlemeden ibaret değildir, bütün organizmayı devreye sokan bir öğrenme çabasıdır.

Okuma sürecini etkileyen pek çok değişken bulunmaktadır. Bu süreçte ortaya çıkabilecek bazı aksaklıklar okumayı olumsuz etkiler. Çocuklarda okumanın gerçekleşmesi onların hem bilişsel hem de dilsel becerilerine bağlıdır. Fakat bazı olumsuz durumlar söz konusu olduğunda bu iki beceri de olumsuz etkilenir ve bu da okuma da hata oluşmasını kaçınılmaz hale getirir. Okuma güçlüğü olarak ifade edilebilecek bu durum çocukların akademik başarısını da olumsuz yönde etkiler. Okuma güçlüğü; yanlış ya da hatalı okumanın yanı sıra okumanın akıcı olmaması ve okuduğunu anlayıp anlatabilme becerisindeki yetersiz olma durumu olarak da görülmektedir (Sarıpınar ve Erden, 2010). Başka bir ifadeyle okuma güçlügüu, bireyin zekâ düzeyinde hiçbir sorun olmamasına karşın okumada meydana gelen aksaklıklar olarak tanımlanabilir.

Bazı öğrenciler amacına uygun olarak verilen okuma-yazma eğitimine karşın okuma güçlüğü yaşadıkları için okuma becerileri edinmelerinde sıkıntılar yaşamaktadırlar. Okuma güçlüğü yaşayan çocuklar okuma becerilerini geliştirmede zorluk yaşadıklarından çok sayıda hata yapabilmekte, okuduğunu anlamada zorluk çekmekte ve akıcı okuyamamaktadır. Bundan dolayı, öğrenmenin ve bilgi sahibi olmanın ana unsuru olan okuma, bireyin hem öğrenim hem de akademik hayatında önemli bir yere sahipken okumada meydana gelen zorluk ise öncelikle bireyin okul hayatı başta olmak üzere hayatında pek çok konuda zorluk yaşamasına sebep olabilmektedir (Sarıkaya, 2011; 8).

Okumada yaşanan zorlukların öğrencinin sadece akademik başarısını değil hem sosyal hem de gelecekteki yaşantısını olumsuz yönde etkileyeceği (Türkmenoğlu ve Baştuğ, 2017) gibi bu da öğrencide öz güven eksikliğini de beraberinde getireceği söylenebilir. 
Bu demek oluyor ki öğrenci okumada zorluk yaşadığında sadece akademik anlamda sıkıntılar yaşamaz bu onun tüm hayatını etkileyen bir problem olarak da karşısına çıkar. Böyle bir durumla baş etmede öğretmenlerin de öğrenciler üzerindeki rolü oldukça önemlidir. Çünkü öğretmen, meydana gelen bu güçlüğü tasvir ederek ona göre öğrenci için bir yol haritası çizmelidir. Öğretmenlerin okuma güçlüğü ile ilgili farkındalık düzeylerinin yeterli olması bu öğrencilerde ileriki yaşlarda oluşabilecek birçok probleminde önüne geçmesine olanak sağlayabilir. Özellikle eğitimciler okuma güçlüğü yaşayan öğrencilerle birebir ilgilenip onların sorunlarını belirleyerek en uygun çözümü üretmelidir (Razon, 1982, Akt. Yüksel, 2010). Bunun için ilk aşamada en önemli olan faktör, öğretmenin çocuğu iyi tanıması ve yaşadığı zorluğun nedenlerinin belirlenmesi olacaktır. Sonrasında ise okuma güçlüğü çeken çocuk tanılanmalı ve düzeyine uygun eğitim planı yapılmalıdır

Okuma güçlüğü çeken öğrencilerin harf veya kelime değiştirme, kelimeye yeni harf veya cümleye kelime ekleme yaptıkları okuma hatalarındandır (Tercan, Kesikçi ve Amado, 2012). Heceleri ve harfleri karıştırmaları, kelime ve cümlelere fazladan eklemeler yapmaları ya da eksik okumaları ve akıcı okuyamamaları sınıf ortamında çocukta okumaya karşı olumsuz tavırlar edinmesine ve isteksiz davranmalarına sebep olmaktadır. Okumada güçlük çeken bireyler gerek eğitim alanında gerekse insanlarla iletişim kurma, değişik bilgileri öğrenme, değişik deneyimleri yaşama vb. konularında da yetersiz kalmaktadırlar (Kardaş İşler ve Şahin, 2016).

Ayrıca okuma güçlüğü yaşayan bireyler, öğrenmelerini engelleyen ve ilerleyen zaman diliminde süreklilik arz eden okuma güçlüğüne ilişkin özelliklerden bazılarına sahiptir ve bu da onların sınıf ortamında tüm derslerde akademik açıdan başarısızlığına neden olmaktadır (Doğan, 2013). Bu yüzden de bu bireylerin erken yaşta doğru bir biçimde tanılanması ve bireye en uygun eğitimin verilmesi durumunda tüm bu yetersizliklerin ve başarısızlıkların en aza indirilmesi hedeflenmelidir. Bu nedenle yapılan araştırmalara bakıldığında birçok araştırmacı tarafından da erken tanı ve müdahale programının önemi vurgulanmıştır (Kaptanoğlu, 2016). Okuma güçlüğü yaşayan çocuğun bireysel özelliğine göre bir programa dâhil edilmesi onun akademik yönden gelişmesini sağlamakta ve bu da beraberinde sağlıklı bir iletişimi getirmektedir. Öğrencilerin bireysel özelliklerine uygun yürütülecek bir program onların eğitimlerinin de en iyi seviyeye geleceğini gösterir (Stuart ve Yates, 2018). Ayrıca öğretmenlerin okuma güçlüğünde kullandıkları eğitsel uygulamalara ilişkin algılarının farklı olması öğrenci başarısını etkiler. Öğrencilerin okuma güçlüğünün giderilmesinde ve onlara akıcı okuma becerisini kazandırmada uygulanacak birçok yöntem vardır (Duran ve Sezgin, 2012). Her öğrencinin bireysel farklılığına ilişkin kullanılacak bu yöntemler öğretmen tarafından çok iyi ve açık bir şekilde belirlenmelidir. Ayrıca öğrencinin ve ailesinin de uygulanacak olan bu programdan haberdar edilerek güvenlerinin kazanılması sağlanmalıdır. Bu nedenle okuma güçlügü yaşayan çocuklara düzeylerine uygun eğitim programı geliştirilmesi açısından erken teşhis edilmesinde öğretmenler kilit noktası olarak görülür. Okuma güçlüğü çeken öğrencilerin özellikle ilk yıllarda belirlenmesi ve uygun yöntemlerle okuma becerilerinin geliştirilmesi bu çocukların kendini rahat bir şekilde ifade etmelerini sağlamaları açısından da önemli olmakla birlikte ileriki yaşlarda karşılaşacakları sorunlara çözüm bulmalarını da kolaylaştıracaktır.

Literatürde okuma güçlüğü yaşayan öğrencilere yönelik araştırmacılar tarafından yapılan müdahale programlarını konu alan (Akyol ve Kodan, 2016; Balcı ve Çayır, 2017; Dağ, 2010; Dinç, 2016; Dündar ve Akyol, 2014; Kuruoğlu ve Şen, 2018; Özkara, 2010; Sezgin ve Akyol, 2015; Sidekli ve Yangın, 2005; Yüksel, 2010) çalışmalarda birçok yöntem ve teknik kullanılmıştır. Çalışmalarda öğrencilerin bireysel farklılıkları da dikkate alınarak geliştirilen farklı müdahale programları uygulanmıştır veya var olan müdahale programlarının okuma 
güçlüğü çeken öğrenciler üzerindeki etkisi incelenmiştir. Bu araştırmanın ilkokullarda öğrenme güçlüğünde kullanılan eğitsel uygulamalarda öğretmenlerin okuma güçlüğü çeken öğrencilerine karşı en uygun yöntem ve teknikleri uygulamaları açısından önemli olduğu düşünülmektedir. Bu bağlamda öğretmenlerin sınıflarında okuma güçlüğü çeken öğrencilerine yönelik gerçekleştirdikleri eğitim uygulamalarına ilişkin algılarını farklı değişkenler açısından belirleyerek, öğretmenlere çözüm önerileri sunması beklenmektedir.

\subsection{Araştırmanın Amacı:}

$\mathrm{Bu}$ araştırmada ilkokullarda okuma güçlüğünde kullanılan eğitsel uygulamalara ilişkin öğretmen algılarının incelenmesi amaçlanmıştır. Bu genel amaç doğrultusunda aşağıdaki sorulara yanıt aranmıştır:

1) İlkokullarda okuma güçlüğünde kullanılan eğitsel uygulamalara ilişkin öğretmen algıları ne düzeydedir?

2) İlkokullarda okuma güçlügüñnde kullanılan eğitsel uygulamalara ilişkin öğretmen algıları cinsiyete göre farklılaşmakta mıdır?

3) İlkokullarda okuma güçlügünde kullanılan eğitsel uygulamalara ilişkin öğretmen algıları kıdemlerine göre farklılaşmakta mıdır?

4) İlkokullarda okuma güçlüğünde kullanılan eğitsel uygulamalara ilişkin öğretmen algıları okutulan sınıf düzeylerine göre değişmekte midir?

5) İlkokullarda okuma güçlügüünde kullanılan eğitsel uygulamalara ilişkin öğretmen algıları sınıflarında okuma güçlüğü yaşayan öğrencisi olma durumuna göre farklılaşmakta mıdır?

6) İlkokullarda okuma güçlüğünde kullanılan eğitsel uygulamalara ilişkin öğretmen algıları okuma güçlügü ile ilgili hizmet içi eğitim alma durumlarına göre farklılaşmakta midir?

\section{ARASTTIRMANIN YÖNTEMI}

\subsection{Araştırmanın Modeli}

$\mathrm{Bu}$ araştırma, ilkokul sınıf öğretmenlerinin ve destek eğitim odasında görev yapan öğretmenlerin, ilkokullarda okuma güçlüğünde kullanılan eğitsel uygulamalara ilişkin algılarının farklı değişkenler açısından incelemek amacıyla yapılan betimsel araştırma modelinden tarama modeline uygun bir araştırmadır. Karasar'a (2005) göre tarama modelleri, önceden ya da halen var olan herhangi bir durumu, bilinen şekliyle betimleyen bir araştırma yaklaşımıdır.

\subsection{Evren ve Örneklem}

Araştırmanın ulaşılabilen evrenini; 2019-2020 eğitim-öğretim yılı Kırşehir il merkezi ve ilçelerindeki ilkokullarda görev yapan sınıf öğretmenleri ile destek eğitim odasında görev yapan öğretmenler; örneklemi ise yansız olarak seçilen 173 öğretmen oluşturmaktadır.

Örneklemde yer alan öğretmenlerin demografik özelliklerine göre yüzde ve frekans dağılımları aşağıda Tablo 1'de yer almaktadır.

Tablo 1. Öğretmenlerin Demografik Özelliklerine Göre Yüzde ve Frekans Dağılımları.

\begin{tabular}{llcc}
\hline Demografik Bilgiler & & f & $\%$ \\
\hline Cinsiyet & Erkek & 80 & 46,2 \\
& Kadın & 93 & 53,8 \\
\hline
\end{tabular}




\begin{tabular}{llcc}
\hline & $1-10$ yıl & 19 & 11,0 \\
Kıdem & $11-20$ yıl & 79 & 45,7 \\
& $21-30$ yıl & 53 & 30,6 \\
& 31 yıl ve üzeri & 22 & 12,7 \\
\hline Sınıf Düzeyi & 1. sınıf & 35 & 20,2 \\
& 2. sınıf & 37 & 21,4 \\
& 3. sınıf & 47 & 27,2 \\
& 4. sınıf & 37 & 21,4 \\
& Destek Eğitim Odası & 17 & 9,8 \\
\hline Sinıfta Okuma Güçlüğü & Evet & 100 & 57,8 \\
Yaşayan Öğrenci Varlığı & Hayır & 73 & 42,2 \\
\hline Okuma Güçlüğü ile İlgili & Evet & 47 & 27,2 \\
Herhangi Bir Kursa & Hayır & 126 & 72,8 \\
Katılma Durumları & & & \\
\hline
\end{tabular}

Tablo 1 verileri incelendiğinde 80 kişinin erkek öğretmenlerden (\%46,2), 93 kişinin ise kadınlardan $(\% 53,8)$ oluştuğu görülmektedir. Verilere bakıldığında öğretmenlerin büyük çoğunluğunu 11-20 arası kıdem yılına sahip olduğu görülmektedir. Bu öğretmenlerin meslek hayatlarındaki kıdemlerine göre dağılımlarına bakıldığında; 1-10 yıl 19(\%11,0) öğretmen, 11 20 y1l 79(\%45,7) öğretmen, 21-30 yıl 53(\%30,6) öğretmen, 31 yıl ve üstünde görev yapan ise $22(\% 12,7)$ öğretmen olduğu görülmektedir. Öğretmenlerin görev yaptıkları sınıf düzeyine göre dağılımlarına bakıldığında; 1.sınıfta 35(\%20,2) öğretmen, 2.sinıfta 37(\%21,4) öğretmen, 3.sınıfta 47(\%27,2) öğretmen, 4.sınıfta 37(\%21,4) öğretmen, destek eğitim odasında ise $17(\% 9,8)$ öğretmen görev yapmaktadır. Öğretmenlerin sınıflarında okuma güçlüğü yaşayan öğrenci durumu sayılarına bakıldığında; 100'ünün $(\% 57,8)$ evet, 73'ünün $(\% 42,2)$ hayır cevabını verdikleri görülmektedir. Son olarak öğretmenlerin okuma güçlügü ile ilgili herhangi bir kursa katılma durumlarına bakıldığında ise; 47'sinin $(\% 27,2)$ evet, 126'sinin $(\% 72,8)$ hayır olarak belirttiği görülmektedir.

\subsection{Veri Toplama Araçları}

Araştırmada verilerin elde edilmesinde Yurdakal ve Susar Kırmızı (2014) tarafından geliştirilen ve 6'lı likert tipindeki 33 maddeden oluşan "Okuma Güçlügünde Kullanılan Ĕgitsel Uygulamalara İlişkin Ögretmen Algıları Ölçeği (OGEUİAÖ)” ile katılımcıların demografik bilgilerinin belirlendiği bir form kullanılmıştır. Ölçeğin Cronbach's Alpha iç tutarlılık katsayısı ise 0,955 olarak elde edilmiştir (Yurdakal, 2014). Bu araştırmaya başlanmadan önce ölçeği geliştiren Yurdakal'dan gerekli izin alınmış olup daha sonrasında ölçek uygulanmaya konulmuştur. Mevcut ölçeğin KMO değeri 0,773 olarak hesaplanıp yeterli düzeyde olduğu belirlenmiştir. Bunun yanı sıra ölçeğin Bartlett Testi düzeyi ise .000 olarak anlamlı bulunmuştur. 33 madde olan ölçek dört alt boyuttan oluşmaktadır.

Birinci faktör; eğitsel etkinlik, ikinci faktör; okuma yazma öğretimi, üçüncü faktör; bilgi edinme ve paylaşma, dördüncü faktör; öğrencilere öneriler olarak isimlendirilmiştir. Ayrıca; ölçekteki 1., 2., 3., 4., 5., 6., 7., 8., 9., 10., 11., 12., 13. ve 14. maddeler birinci alt boyutta, 15., 16., 17., 18., 19., 20., 21. ve 22. maddeler ikinci alt boyutta, 23., 24., 25., 26., 27. ve 28. maddeler üçüncü alt boyutta, 29., 30., 31., 32. ve 33. maddeler ise dördüncü alt boyutta yer almaktadir. 


\subsection{Verilerin Toplanması ve Analizi}

Araştırmada kullanılan veriler Yurdakal ve Susar Kırmızı (2014) tarafından geliștirilen “Okuma Güçlügünde Kullanılan Ĕgitsel Uygulamalara İlişkin Öğretmen Algıları Ölçeği (OGEUIAÖ"ile elde edilmiştir. Araştırmada kullanılan verilerin toplanması elektronik ortamda gerçekleştirilmiştir. Ölçme aracı elektronik ortam üzerinden hazırlanarak öğretmenlere ulaşılmaya çalışılmış ve ölçek araştırmaya katılan toplam 173 öğretmenlere yine elektronik ortamda (whatsapp) doldurtulmuştur. Araştırma ile ilgili etik kurul onayı Kırşehir Ahi Evran Üniversitesi Eğitim Fakültesi Etik Kurulu'ndan alınmıştır.

Daha sonra araştırmada uygulanan istatistiksel analizler SPSS istatistik paket programı ile gerçekleştirilmiştir. Veriler değerlendirilirken betimsel istatistikler kullanılmıştır. Verilerin analizinde $\mathrm{p}<.05$ güvenirlik düzeyi olarak ele alınmıştır. Araştırma verilerinin normal dağılım gösterdiği tespit edildiğinden analizlerde parametrik testler kullanılmıştır.

Tablo 2. Okuma Güçlügünde Kullanılan Eğitsel Uygulamalara İlişkin Öğretmen Algılarının Normallik Dağılımları

\begin{tabular}{lccc}
\hline Kolmogorov-Smirnov $^{\text {a }}$ & Statistik & df & $p$ \\
\hline GENEL & 0,65 & 173 & 0,74 \\
\hline
\end{tabular}

Tablo 2'de Kolmogrov-Smirnov değerine bakıldığında ,074 olduğu tespit edilmiştir. Veriler p(sig) değerinin $.05^{\prime}$ in üzerindedir. Bu da dağılım normal olduğunu göstermektedir. Veriler normal dağılım gösterdiğinden verilerin analizinde ikili değişkenler için bağımsız gruplar $t$ testi kullanılmış olup çoklu değişkenler için tek yönlü varyans analizi (ANOVA) kullanılmıştır.

Ölçek maddeleri sınıf öğretmenlerinin ve destek eğitim odasında görev yapan öğretmenlerin vermiş olduğu cevaplar cinsiyet, kıdem, görev yaptıkları sınıf düzeyi, sınıflarında okuma güçlügü yaşayan öğrenci varlığı ve okuma güçlüğü ile ilgili herhangi bir kursa katılma durumları değişkenlerine göre değerlendirilmeye alınmıştır. Ölçek maddelerinde 1 "hiç katılmıyorum", 2 "katılmıyorum", 3 "kısmen katılmıyorum", 4 "kismen kat1liyorum", 5 "katılıyorum", 6 "tamamen katılıyorum” şeklinde alınmıştır. En yüksek puan 198 puan olarak hesaplanmıştır. Kullanılan ölçeğe verilen cevapların değerlendirilmesinde Tablo 4 'teki aralıklar kullanılmıştır. Aralıkların eşit olduğu varsayılmış, aritmetik ortalamalar için puan aralığ 10,83 olarak hesaplanmıştır (Puan Aralığ $1=(\mathrm{n}-1) / \mathrm{n} ;(6-5) / 6=0,83)$.

Tablo 3. Okuma Güçlüğünde Kullanılan Eğitsel Uygulamalara İlişkin Öğretmen Algıları Ölçeği Hesaplanırken Kullanılan Aralıklar

\begin{tabular}{cc}
\hline Sinırı & Seçenek \\
\hline $1,00-1,83$ & Hiç Katıllmıyorum \\
$1,84-2,67$ & Katılmıorum \\
$2,67-3,50$ & Kismen Katılmıyorum \\
$3,50-4,33$ & Kısmen Katılıyorum \\
$4,33-5,17$ & Katılıyorum \\
$5,16-6,00$ & Tamamen Katılıyorum \\
\hline
\end{tabular}

Anadolu Kültürel Araştırmalar Dergisi (ANKAD) 


\section{BULGULAR}

Araştırma kapsamında ilkokul sınıf öğretmenlerine ve destek eğitim odasında görev yapan öğretmenlere uygulanan "Okuma Güçlüğünde Kullanılan Eğitsel Uygulamalara İlişkin Öğretmen Algıları Ölçeği'nin (OGEUİAÖ)" farklı değişkenlere göre nasıl sonuçlandığı araştırma alt problemleri kapsamında değerlendirilmiştir.

Tablo 4. İlkokullarda Okuma Güçlüğünde Kullanılan Eğitsel Uygulamalara İlişkin Öğretmen Algılarının Dağılımları.

\begin{tabular}{|c|c|c|c|c|}
\hline & $\mathrm{N}$ & $\overline{\mathrm{X}}$ & SS & Düzey \\
\hline Eğitsel Etkinlik & 173 & 5,42 & ,376 & $\begin{array}{l}\text { Tamamen } \\
\text { Kat1liyorum }\end{array}$ \\
\hline $\begin{array}{l}\text { Okuma Yazma } \\
\text { Öğretimi }\end{array}$ & 173 & 5,43 & 380, & $\begin{array}{l}\text { Tamamen } \\
\text { Katıliyorum }\end{array}$ \\
\hline $\begin{array}{l}\text { Bilgi Edinme ve } \\
\text { Paylaşma }\end{array}$ & 173 & 5,22 & ,501 & $\begin{array}{l}\text { Tamamen } \\
\text { Katıliyorum }\end{array}$ \\
\hline $\begin{array}{l}\text { Öğrencilere } \\
\text { Öneriler }\end{array}$ & 173 & 5,37 & ,336 & $\begin{array}{c}\text { Tamamen } \\
\text { Katıliyorum }\end{array}$ \\
\hline GENEL & 173 & 5,29 & ,470 & $\begin{array}{c}\text { Tamamen } \\
\text { Katıliyorum }\end{array}$ \\
\hline
\end{tabular}

Tablo 4 verilerine bakıldığında ilkokullarda okuma güçlüğünde kullanılan eğitsel uygulamalara ilişkin öğretmen algılarının genel ortalamaları $\bar{x}=5,29$ ile tamamen katılıyorum düzeyinde olduğu tespit edilmiştir. Ölçeğin alt boyutlarındaki veriler incelendiğinde "eğitsel etkinlik" alt boyutunda öğretmenlerin ortalamasının $\bar{x}=5,42$ ile tamamen katılıyorum düzeyinde; "okuma yazma öğretimi" alt boyutunda öğretmenlerin ortalamasının $\bar{x}=5,43$ ile tamamen katıliyorum düzeyinde; "bilgi edinme ve paylaşma" alt boyutunda öğretmenlerin ortalamasının $\bar{x}=5,22$ ile tamamen katılıyorum düzeyinde; "öğrencilere öneriler" alt boyutunda öğretmenlerin ortalamasının $\overline{\mathrm{x}}=5,37$ ile tamamen katılıyorum düzeyinde görüş bildirdikleri görülmektedir. $\mathrm{Bu}$ bulgularla öğretmenlerin okuma güçlüğünde kullanılan eğitsel uygulamalara ilişkin algılarının olumlu düzeyde olduğu söylenebilir.

Tablo 5. Cinsiyet Değişkenine Göre Öğretmenlerin İlkokullarda Okuma Güçlüğünde Kullanılan Eğitsel Uygulamaya İlişkin Algılarının T Testi Sonuçları.

\begin{tabular}{lccccccc} 
& Cinsiyet & $\mathrm{N}$ & $\overline{\mathrm{X}}$ & $\mathrm{SS}$ & $\mathrm{T}$ & $\mathrm{p}$ & Cohen d \\
\hline Eğitsel Etkinlik & Erkek & 85 & 5,34 &, 402 &,- 703 &, 285 & --- \\
& Kadın & 99 & 5,39 &, 562 & & & \\
Okuma Yazma & Erkek & 85 & 5,35 &, 453 & $-1,073$ &, 993 & --- \\
Öğretimi & Kadın & 99 & 5,42 &, 440 & & & \\
Bilgi Edinme ve & Erkek & 85 & 5,22 &, 547 &,- 287 &, 999 & --- \\
Paylaşma & Kadın & 99 & 5,24 &, 634 & & & \\
\multirow{2}{*}{ Öğrencilere Öneriler } & Erkek & 85 & 5,09 &, 584 & $-1,579$ &, 717 & --- \\
& Kadın & 99 & 5,23 &, 641 & & & \\
GENEL & Erkek & 85 & 5,33 &, 314 & $-1,398$ &, 093 & --- \\
& Kadın & 99 & 5,40 &, 351 & & & \\
\hline
\end{tabular}


Tablo 5'te öğretmenlerin okuma güçlüğünde kullanılan eğitsel uygulamalara ilişkin algılarının cinsiyete göre anlamlı bir farkın olup olmadığını belirlemek için bağımsız gruplar t-testi kullanılmıştır. Öğretmenlerin ilkokullarda okuma güçlüğünde kullanılan eğitsel uygulamalara ilişkin algıları ile cinsiyet değişkeni arasında anlamlı bir farkın olmadığı tespit

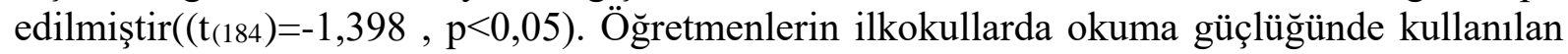
eğitsel uygulamalara ilişkin algıları ölçeğin "eğitsel etkinlik", "okuma yazma öğretimi”, "bilgi edinme ve paylaşma" ve "öğrencilere öneriler" alt boyutları ile cinsiyetleri arasında istatistiksel olarak 0,05 düzeyinde anlamlı değildir. Bunun sonucunda cinsiyet faktörünün ilkokullarda okuma güçlüğünde kullanılan eğitsel uygulamalara ilişkin öğretmen algılarını etkilemediği söylenebilir.

Tablo 6. Mesleki Kıdeme Göre Öğretmenlerin İlkokullarda Okuma Güçlüğünde Kullanılan Eğitsel Uygulamaya İlişkin Algılarının ANOVA Sonuçları.

\begin{tabular}{|c|c|c|c|c|c|c|c|}
\hline & $\begin{array}{l}\text { Varyansın } \\
\text { Kaynağ1 }\end{array}$ & $\begin{array}{l}\text { Kareler } \\
\text { toplamı }\end{array}$ & $\mathrm{df}$ & $\begin{array}{c}\text { Kareler } \\
\text { ortalaması }\end{array}$ & $\mathrm{F}$ & $\mathrm{p}$ & $\begin{array}{l}\text { Anlamlı } \\
\text { Fark }\end{array}$ \\
\hline \multirow{3}{*}{ Eğitsel Etkinlik } & Gruplar arası & ,361 & 3 &, 120 & ,846 & ,470 & --- \\
\hline & Grup içi & 24,022 & 169 & ,142 & & & \\
\hline & Toplam & 24,383 & 172 & & & & \\
\hline \multirow{3}{*}{$\begin{array}{l}\text { Okuma Yazma } \\
\text { Öğretimi }\end{array}$} & Gruplar aras1 & ,366 & 3 & , 122 & ,840 & ,474 & --- \\
\hline & Grup içi & 24,556 & 169 & ,145 & & & \\
\hline & Toplam & 24,922 & 172 & & & & \\
\hline \multirow{3}{*}{$\begin{array}{l}\text { Bilgi Edinme ve } \\
\text { Paylaşma }\end{array}$} & Gruplar aras1 &, 093 & 3 & ,031 & ,138 & ,937 & --- \\
\hline & Grup içi & 38,035 & 169 & 225 & & & \\
\hline & Toplam & 38,129 & 172 & & & & \\
\hline \multirow{3}{*}{ Öğrencilere Öneriler } & Gruplar aras1 & 1,887 & 3 & ,629 & 2,574 & ,056 & --- \\
\hline & Grup içi & 41,296 & 169 & ,244 & & & \\
\hline & Toplam & 43,183 & 172 & & & & \\
\hline \multirow{3}{*}{ GENEL } & Gruplar aras1 & ,371 & 3 &, 124 & 1,096 & ,353 & --- \\
\hline & Grup içi & 19,067 & 169 &, 113 & & & \\
\hline & Toplam & 19,438 & 172 & & & & \\
\hline
\end{tabular}

Tablo 6' da öğretmenlerin okuma güçlüğünde kullanılan eğitsel uygulamalara ilişkin algılarının meslekteki kıdeme göre farklılaşma durumunu belirlemede tek yönlü varyans analizi (ANOVA) kullanılmıştır. Veriler incelendiğinde, öğretmenlerin "okuma güçlüğünde kullanılan eğitsel uygulamalara" ilişkin algılarında mesleki kıdeme göre anlamlı bir farklılığın olmadığ tespit edilmiştir ( $p=0.353, p>0.05)$. Ölçeğin "eğitsel etkinlik $(p=0.470, p>0.05)$ " , "okuma yazma öğretimi ( $p=0,474, p>0.05)$ ", "bilgi edinme ve paylaşma $(p=0.937, p>0.05)$ " ve "öğrencilere öneriler $(\mathrm{p}=0.056, \mathrm{p}>0.05)$ " alt boyutları ile meslekteki kıdemleri arasında istatistiksel olarak 0,05 düzeyinde anlamlı bir farkın olmadığı tespit edilmiştir. Buna göre öğretmenlerin mesleki kıdemlerinin okuma güçlüğünde kullanılan eğitsel uygulamalara ilişkin algılarını etkileyen bir değişken olmadığı söylenebilir. 
Tablo 7. Okutulan sınıf düzeyine Göre Öğretmenlerin İlkokullarda Okuma Güçlüğünde Kullanılan Eğitsel Uygulamaya İlişkin Görüşlerinin ANOVA testi.

\begin{tabular}{|c|c|c|c|c|c|c|c|}
\hline & $\begin{array}{c}\text { Varyansın } \\
\text { Kaynağ1 }\end{array}$ & $\begin{array}{l}\text { Kareler } \\
\text { toplamı }\end{array}$ & df & $\begin{array}{c}\text { Kareler } \\
\text { ortalaması }\end{array}$ & $\mathrm{F}$ & $\mathrm{p}$ & $\begin{array}{l}\text { Anlamlı } \\
\text { Fark }\end{array}$ \\
\hline \multirow{3}{*}{ Eğitsel Etkinlik } & Gruplar arası &, 502 & 4 &, 125 & ,883 & ,476 & --- \\
\hline & Grup içi & 23,881 & 168 &, 142 & & & \\
\hline & Toplam & 24,383 & 172 & & & & \\
\hline \multirow{3}{*}{$\begin{array}{l}\text { Okuma Yazma } \\
\text { Öğretimi }\end{array}$} & Gruplar arası & ,269 & 4 & 067 & ,459 & ,766 & --- \\
\hline & Grup içi & 24,653 & 168 & ,147 & & & \\
\hline & Toplam & 24,922 & 172 & & & & \\
\hline \multirow{3}{*}{$\begin{array}{l}\text { Bilgi Edinme ve } \\
\text { Paylaşma }\end{array}$} & Gruplar arası & 1,502 & 4 &, 375 & 1,722 &, 147 & --- \\
\hline & Grup içi & 36,627 & 168 &, 218 & & & \\
\hline & Toplam & 38,129 & 172 & & & & \\
\hline \multirow{3}{*}{ Öğrencilere Öneriler } & Gruplar arası & 1,579 & 4 & ,395 & 1,594 &, 178 & --- \\
\hline & Grup içi & 41,604 & 168 & ,248 & & & \\
\hline & Toplam & 43,183 & 172 & & & & \\
\hline \multirow{3}{*}{ GENEL } & Gruplar arası & ,605 & 4 &, 151 & 1,349 &, 254 & --- \\
\hline & Grup içi & 18,833 & 168 &, 112 & & & \\
\hline & Toplam & 19,438 & 172 & & & & \\
\hline
\end{tabular}

Tablo 7'de öğretmenlerin okuma güçlüğünde kullanılan eğitsel uygulamalara ilişkin algılarının okuttukları sınıf düzeyine göre anlamlı olup olmadığını belirlemek için tek yönlü varyans analizi (ANOVA) kullanılmıştır. Öğretmenlerin okuttukları sınıf düzeylerine göre okuma güçlügüünde kullanılan eğitsel uygulamalara ilişkin algıları arasında istatistiksel olarak anlamlı bir fark bulunmadığı tespit edilmiştir $(p=0.254, p>0.05)$. Ölçeğin alt boyutlarına bakıldı ğında da "eğitsel etkinlik ( $p=0.476, p>0.05)$ ", "okuma yazma öğretimi $(p=0,766, p>0.05)$ ", "bilgi edinme ve paylaşma ( $\mathrm{p}=0.147, \mathrm{p}>0.5)$ " ve "öğrencilere öneriler ( $\mathrm{p}=0.178, \mathrm{p}>0.05)$ " alt boyutları ile meslekteki kıdemleri arasında istatistiksel olarak 0,05 düzeyinde anlamlı bir farkın olmadığ görülmektedir.

Tablo 8. Sınıflarında Okuma Güçlügü Yaşayan Öğrenci Durumuna Göre Öğretmenlerin İlkokullarda Okuma Güçlügünde Kullanılan Eğitsel Uygulamaya İlişkin Algılarının T-Testi Sonuçları

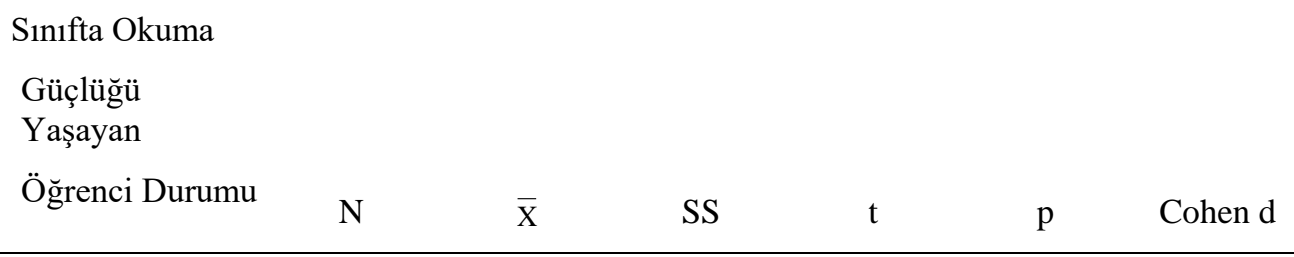




\begin{tabular}{llcccccc}
\hline Eğitsel Etkinlik & Evet & 100 & 5,41 &, 348 &,- 479 &, 633 & --- \\
& Hayır & 73 & 5,44 &, 413 & & & \\
Okuma Yazma & Evet & 100 & 5,44 &, 387 &, 492 &, 623 & --- \\
Öğretimi & Hayır & 73 & 5,41 &, 372 & & & \\
Bilgi Edinme ve & Evet & 100 & 5,34 &, 438 & 1,673 &, 096 & --- \\
Paylaşma & Hayır & 73 & 5,22 &, 506 & & & \\
Öğrencilere & Evet & 100 & 5,21 &, 520 &,- 336 &, 738 & - -- \\
Öneriler & Hayır & 73 & 5,24 &, 475 & & & \\
\multirow{2}{*}{ GENEL } & Evet & 100 & 5,37 &, 310 &, 169 &, 866 & --- \\
& Hayır & 73 & 5,36 &, 370 & & & \\
\hline
\end{tabular}

Tablo 8'da öğretmenlerin okuma güçlüğünde kullanılan eğitsel uygulamalara ilişkin algılarının sınıflarında okuma güçlüğü yaşayan öğrenci durumuna göre anlamlı olup olmadığını belirlemek için bağımsız gruplar t-testi kullanılmıştır. Öğretmenlerin sınıflarında okuma güçlüğü yaşayan öğrenci durumuna okuma güçlügünde kullanılan eğitsel uygulamalara ilişkin algıları arasında istatistiksel olarak anlamlı bir fark bulunmadığı tespit edilmiştir $(p=0.866$, $\mathrm{p}>0.05)$.

Tablo 9. Okuma Güçlüğü ile İlgili Herhangi Bir Kursa Katılma Durumuna Göre Öğretmenlerin İlkokullarda Okuma Güçlüğünde Kullanılan Eğitsel Uygulamaya İlişkin Algılarının T -Testi Sonuçları

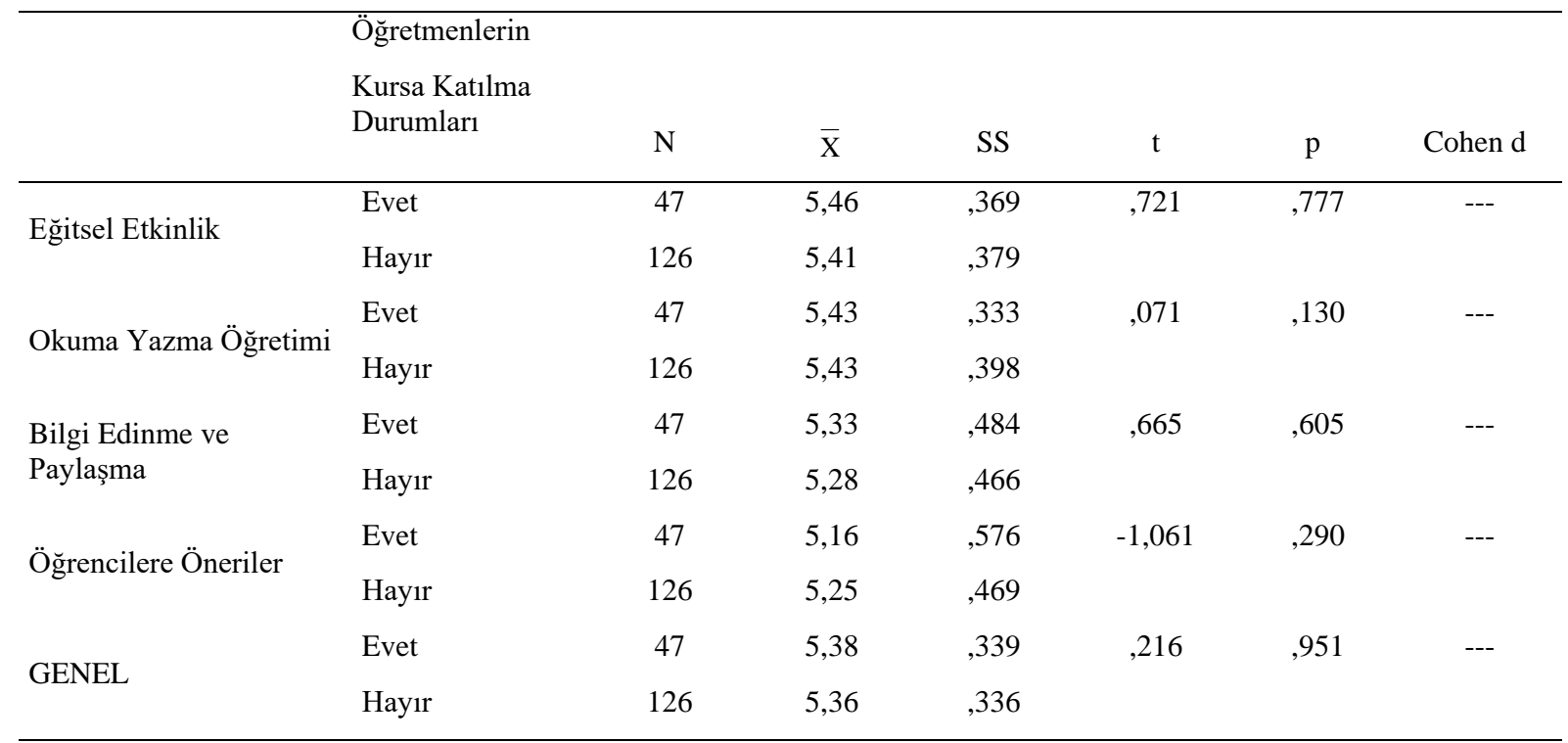

Tablo 9 verileri incelendiğinde öğretmenlerin okuma güçlüğü ile ilgili herhangi bir kursa katılma durumları ile ilkokullarda okuma güçlüğünde kullanılan eğitsel uygulamaya ilişkin algıları arasında anlamlı bir farkın olmadığı tespit edilmiştir $(p=0.951, p>0.05)$. Ölçeğin alt boyutlarına bakıldığında "eğitsel etkinlik $(p=0.777, p>0.05)$ ", "okuma yazma öğretimi ( $p=$ $0,130, p>0.05)$ ", "bilgi edinme ve paylaşma $(p=0.605, p>0.5)$ " ve "öğrencilere öneriler $(p=$ $0.290, \mathrm{p}>0.05$ )" alt boyutları ile öğretmenlerin okuma güçlüğü ile ilgili herhangi bir kursa katılma durumları arasında istatistiksel olarak 0,05 düzeyinde anlamlı bir farkın olmadığı tespit edilmiştir. Öğretmenlerin okuma güçlüğü ile ilgili herhangi bir kurs alıp almamaları onların 
okuma güçlügünde kullanılan eğitsel uygulamalara ilişkin algılarını anlamlı düzeyde etkilemediği söylenebilir.

\section{SONUÇ, TARTIŞMA ve ÖNERILER}

"İlkokullarda okuma güçlüğünde kullanılan eğitsel uygulamalara ilişkin öğretmen algılarının incelenmesi" adlı araştırma kapsamında hem ilkokul sınıf öğretmenlerinin hem de destek eğitim odasında görev yapan öğretmenlerin okuma güçlüğünde kullanılan eğitsel uygulamalara ilişkin algıları cinsiyete, mesleki kıdeme, okuttukları sınıf düzeyine, sınıflarında okuma güçlüğü yaşayan öğrenci durumuna ve okuma güçlüğü ile ilgili herhangi bir kursa katılma durumuna göre incelenmiştir. Araştırma verilerinden elde edilen sonuçlara göre;

Okuma güçlüğünde kullanılan eğitsel uygulamalara ilişkin öğretmen algıları incelendiğinde genel ortalamalarının tamamen katılıyorum düzeyinde yüksek çıktığı görülmüştür. Bu da öğretmenlerin okuma güçlügünde kullanılan eğitsel uygulamalara ilişkin algılarının olumlu yönde olduğunu göstermektedir. Kodan (2020) yaptığı araştırmada sınıf öğretmenlerinin okuma güçlügüne ilişkin bilgilerinde eksiklik olduğunu tespit etmiş fakat genel olarak bilgi düzeylerinin yüksek olduğu sonucuna ulaşmıştır. Ketenoğlu Kayabaşı (2019) yaptığı çalışmada öğretmenlerin okuma güçlüğü kavramı ile ilgili bilgi ve algı seviyelerinin iyi düzeyde olduğunu ifade etmiştir. Bu sonuçlar, araştırmanın sonucu ile benzerlik göstermektedir. Doğan (2013) yaptığı araştırmanın genel sonuçları değerlendirildiğinde okuma güçlügü konusunda araştırmaya katılan Türkçe ve sınıf öğretmenlerinin okuma güçlüğü konusunda yeterli bilgiye sahip olmadıklarını tespit etmiştir. Ayrıca görüşme yapılan öğretmenler okuma güçlüğü çeken öğrencileri belirleyebilme ve bu öğrenciler için yapılması gerekenler konusunda kendilerini tam olarak yeterli görmediklerini belirtmişlerdir. Altun, Ekiz ve Odabaşı (2011) yaptıkları çalışmada sınıf öğretmenlerinin birçok okuma güçlüğü yaşayan öğrenci ile karşılaştıkları ve bu güçlüğü gidermek için çeşitli uygulamalar yaptıkları buna rağmen öğretmenlerin okuma güçlüğü hakkında tam anlamıyla kendilerini yeterli bulmadıkları sonucuna ulaşmışlardır. $\mathrm{Bu}$ sonuçlar, araştırmanın sonucundan farklılık göstermektedir.

Sınıf ve destek eğitim odasında görev yapan öğretmenlerin okuma güçlüğünde kullanılan eğitsel uygulamalara ilişskin algıları ile cinsiyet arasında anlamlı bir farklılık yoktur. Bu bağlamda erkek ve kadın öğretmenlerin okuma güçlüğü çeken öğrencilere uygulanan eğitsel uygulamalarda aynı özeni gösterdikleri söylenebilir. Akçay (2014) "ilkokul 1-4. sınıf öğretmenlerinin disleksi ile farkındalık düzeylerinin incelenmesi” adlı tez çalışmasında ilkokul sınıf öğretmenlerinin disleksi ile ilgili farkındalık düzeyleri öğretmenlerin cinsiyetine göre istatistiksel olarak anlamlı bir farkın olup olmadığını bulmayı amaçlamıştır. Çıkan sonuçlarda ilkokul sınıf öğretmenlerinin disleksi ile ilgili farkındalık düzeyleri öğretmenlerin cinsiyetine göre istatistiksel olarak anlamlı düzeyde farklılaşmadığını tespit etmiştir. Bu durum her iki araştırmanın da cinsiyet değişkeni sonuçları bakımından benzer olduğunu göstermektedir. Yiğiter (2005) "Sınıf öğretmenlerinin özel öğrenme güçlüğüne ilişkin bilgi düzeyleri ile özel öğrenme güçlüğü olan çocukların kaynaştırılmasına yönelik tutumları arasındaki ilişkinin incelenmesi” adlı araştırmasında sınıf öğretmenlerinin özel öğrenme güçlüğüne ilişkin bilgi düzeylerinin, cinsiyete göre farklılık gösterdiği sonucu ile bu araştırmanın cinsiyet değişkeni ile benzer olmadığını göstermektedir.

Sınıf ve destek eğitim odasında görev yapan öğretmenlerin okuma güçlüğünde kullanılan eğitsel uygulamalara ilişkin algıları ile mesleki kıdemleri arasında ölçeğin genel ve alt boyutlarına bakıldığında anlamlı bir farkın olmadığı görülmektedir. Bu durum, öğretmenlerin meslekteki görev sürelerindeki farklılığın, okuma güçlügünde kullanılan eğitsel uygulamalara ilişkin öğretmen algılarında herhangi bir etkiye sahip olmadığı görüşünü desteklediği söylenebilir. Yurdakal (2014) yaptığı araştırmada sınıf öğretmenlerinin okuma güçlüğü olan 
öğrenciler için yaptıkları eğitsel uygulamalara yönelik algıları ile kıdemleri arasında anlamlı bir farklılığın olduğunu tespit etmiştir .11-15 yıl arası kıdeme sahip olan öğretmenlerin okuma güçlüğü olan öğrenciler için yaptıkları eğitsel uygulamalara yönelik algıları diğer öğretmenlere göre daha düşük olduğunu belirlemiş ve bu araştırmanın mesleki kıdem değişkeni sonucu ile benzer olmadığ 1 görülmüştür.

Sınıf ve destek eğitim odasında görev yapan öğretmenlerin okuma güçlügüunde kullanılan eğitsel uygulamalara ilişkin algıları ile okuttukları sınıf düzeyi arasında anlamlı bir farklılık yoktur. Bu bağlamda 1. sınıfı, 2. sınıfı, 3. sınıfı, 4. sınıfı okutan öğretmenlerin ve destek eğitim odasında görev yapan öğretmenlerin hangi sınıfı okuturlarsa okutsunlar bu öğrencilere karşı uyguladıkları eğitsel uygulamalarda tecrübeli oldukları söylenebilir.

Sınıf ve destek eğitim odasında görev yapan öğretmenlerin okuma güçlüğünde kullanılan eğitsel uygulamalara ilişkin algıları ile sınıflarında okuma güçlüğü yaşayan öğrenci durumu ile aralarında anlamlı bir fark yoktur. Bu durumda öğretmenlerin, sınıflarında okuma güçlüğü yaşayan öğrenci olsa da olmasa da daha önceki yıllarda okuma güçlüğü yaşayan öğrenci ile karşılaştıkları veya okuma güçlügü ile ilgili bilgi sahibi oldukları söylenebilir. Altuntaş (2010) araştırmasında da sınıf öğretmenlerinin disleksiye ilişkin bilgilerinin, sınıflarında dislektik öğrenci olma durumuna göre farklılaşmadığ 1 sonucuna ulaşmıştır. $\mathrm{Bu}$ araştırma sonucu ile benzer nitelik göstermektedir.

Okuma güçlüğü ile ilgili herhangi bir kursa katılma durumuna göre katılmayan öğretmenlerin katılanlara oranla fazla olsa da öğretmenlerin ilkokullarda okuma güçlüğünde kullanılan eğitsel uygulamaya ilişkin algıları arasında anlamlı fark yoktur. Bu sonucun öğretmenlerin öğrenme güçlügü hakkındaki bilgilerinin, öğrenme güçlüğü ile ilgili herhangi bir kurs almasa da çeşitli kaynaklardan edindikleri bilgiler ve tecrübelerle desteklendiği söylenebilir. Firat ve Koçak (2018) yaptıkları araştırmada araştırmaya katılan öğretmenlerin büyük bir çoğunluğunun öğrenme güçlüğü ile ilgili herhangi bir ders veya kurs almadığını, alan öğretmenlerin ise özel eğitim dersi kapsamında veya kısa süreli kurslar aldığını belirlemişlerdir.

\section{Öneriler}

Araştırma sonucuna bakılarak elde edilen bilgiler doğrultusunda; her ne kadar öğretmenlerin, yaptıkları eğitsel uygulamalara ilişkin algıları yüksek olsa da öğretmenlerin mesleki kıdemleri fark etmeksizin her yaş grubuna okuma güçlügü ile ilgili çeşitli kurslar verilerek farkındalığın daha da arttırılması sağlanabilir. Öğretmenlerin genel olarak okuma güçlüğü yaşayan öğrencilerine farklı eğitsel uygulamalar yaptıkları görülmekte ve bununla ilgili daha fazla kaynak ve materyal sağlandığında daha olumlu sonuçların ortaya çıkacağı düşünülmektedir. Bu konuda göreve yeni başlayan öğretmenlere okuma güçlüğünde kullanılan eğitsel uygulamalara ilişkin MEB tarafından çeşitli eğitimler verilebilir. İleriki araştırmalara öneri olarak; öğretmenlerin okuma güçlüğü ile ilgili herhangi bir kursa katılmadıkları halde okuma güçlüğünde kullandıkları eğitsel uygulamalara ilişkin bilgi açığını nasıl kapattıkları hakkında nitel bir araştırma yapılabilir. Ayrıca öğretmenlerin okuma güçlüğ̈ yaşayan öğrencilere yönelik hangi eğitim uygulamalarını kullanacakları hakkında nerelerde sorun yaşadıkları ve hangi uygulamaların okuma güçlügü çeken öğrencinin yararına olacağı ile ilgili bir çalışma yapılabilir.

\section{KAYNAKÇA}

Akçay, D. (2014). İlkokul 1-4. Sinıf ögrretmenlerinin disleksi ile farkındalık düzeylerinin incelenmesi. Marmara Üniversitesi Eğitim Bilimleri Enstitüsü, İstanbul. 
Akyol, H. \& Kodan, H. (2016). Okuma güçlüğünün giderilmesine yönelik bir uygulama: Akıc1 okuma stratejilerinin kullanımı. Ondokuz Mayıs Üniversitesi Eğitim Fakültesi Dergisi 35 (2), 7-21.

Altun, T., Ekiz, D. \& Odabaşi, M. (2011). Sınıf öğretmenlerinin sınıflarında karşılaştıkları okuma güçlüklerine ilişsin nitel bir araştırma. Dicle Üniversitesi Ziya Gökalp Ĕ̈itim Fakültesi Dergisi, 17, 80-101

Altuntaş, F. (2010). Sinıf öğretmenlerinin disleksiye ilişkin bilgileri ve dislektik öğrencilere yönelik çalışmaları. Hacettepe Üniversitesi, Ankara.

Balcı, E. \& Çayır, A. (2017). Disleksi riski taşıyan 4. sınıf öğrencisinin fonolojik farkındalığının arttırılmasında çoklu duyusal öğrenmenin etkisi. Ana Dili Ĕ̆itimi Dergisi, 5(2), 201-216.

Dağ, N. (2010). Okuma güçlüğünün giderilmesinde 3p metodu ile boşluk tamamlama (cloze) tekniğinin kullanımı üzerine bir çalışma. Ankara Üniversitesi Eğitim Bilimleri Fakültesi Özel Eğitim Dergisi, 11(1),63-74.

Dinç, R. (2016). Okuma güçlüğü yaşayan öğrencide okuma becerisini geliştirmeye yönelik bir eylem araştırması. Kuramsal Ĕgitimbilim Dergisi, 10(2), 320-334.

Doğan, B. (2013). Türkçe ve sınıf öğretmenlerinin okuma güçlüğüne ilişkin bilgileri ve okuma güçlüğü olan öğrencileri belirleyebilme düzeyleri. Okuma Yazma Eğitimi Araştırmaları, 1(1), 20-33.

Dündar, H. \& Akyol, H. (2014). Okuma ve anlama problemlerinin tespiti ve giderilmesine örnek olay çalışması. Eğitim ve Bilim, 39 (171), 361-377.

Fırat, T. \& Koçak, D. (2018). Sınıf öğretmenlerinin öğrenme güçlüğünün tanımına ilişkin görüşleri. Abant İzzet Baysal Üniversitesi Eğitim Fakültesi Dergisi, 18(2), 915-931.

Karasar, N. (2005). Bilimsel araştırma yöntemi. 15. Bask1. Ankara: Nobel Yayın Dağıtım.

Ketenoğlu Kayabaşı, Z. E. (2019). Sinıf öğretmenlerinin okuma güçlüklerine ilişkin görüş ve uygulamaları. Gazi Üniversitesi, Eğitim Bilimleri Enstitüsü, Ankara.

Kodan, H. (2020). Okuma güçlüğüne ilişkin öğretmen görüşleri. Bayburt Eğitim Fakültesi Dergisi, 15(29), 204-222.

Kuruoğlu, G. \& Nilay, Ş. E. N. (2018). Okuma güçlüğü yaşayan ortaokul öğrencilerin yaptıkları okuma hatalarının incelenmesi. Ĕgitim Kuram ve Uygulama Araştırmaları Dergisi, 4(2), 101-110.

Özkara, Y. (2010). Okuma güçlüğü olan öğrencilerin okuma düzeylerinin geliştirilmesine yönelik bir uygulama. Pamukkale Üniversitesi Sosyal Bilimler Enstitüsü Dergisi, 5, 109119.

Sarıkaya, E. (2011). İşitme engelli çocukların öğretmenlerinin işitme engelli çocukların okuma yazma ögrenmelerine ilişkin görüş ve önerileri. (Yayımlanmamış Yüksek Lisans Tezi). Anadolu Üniversitesi Eğitim Bilimleri Enstitüsü, Eskişehir.

Sarıpınar, E. G. \& Erden, G. (2010). Okuma güçlüğünde akademik beceri ve duyusal-motor işlevleri değerlendirme testlerinin kullanılabilirliği. Türk Psikoloji Dergisi, 25(65), 5666.

Sezgin, Z.Ç. \& Akyol, H. (2015). Okuma güçlügü olan dördüncü sınıf öğrencisinin okuma becerilerinin geliştirilmesi. Turkish Journal of Education, 4(2), 4-16. 
Sidekli, S. \& Yangın, S. (2005). Okuma güçlügü olan ögrencilerin okuma becerilerinin geliştirilmesine yönelik bir uygulama. Kazım Karabekir Eğitim Fakültesi Dergisi, 11,393-413.

Stuart, A. \& Yates, A. (2018). Inclusive classroom strategies for raising the achievement of students with dyslexia. New Zealand Journal of Teachers' Work, 15(2), 100-104.

Tercan, E. A., Kesikçi, H. \& Amado, S. (2012). Okuma Güçlüğü Yaşayan Çocuklarda Çalışma Belleğinin Fonolojik Depo Açısından İncelenmesi. Türk Psikoloji Dergisi, 27(69), 65-75.

Türkmenoğlu, M. \& Baştuğ, M. (2017). İlkokulda akran öğretimi aracılığıyla okuma güçlüğünün giderilmesi. Eğitimde Nitel Araştırmalar Dergisi, 5(3), 36-66.

Yiğiter, S. (2005). Sınff öğretmenlerinin özel öğrenme güçlüğüne ilişkin bilgi düzeyleri ile özel ögrenme güçlügü olan çocukların kaynaştırılmasına yönelik tutumları arsındaki ilişkinin incelenmesi. Yüksek Lisans Tezi, Marmara Üniversitesi Eğitim Bilimleri Enstitüsü, İstanbul

Yurdakal, İ. H. (2014). Illkokullarda okuma güçlüğünde yaşanan sorunlar ile e ğitim uygulamalarına ilişkin ögretmen ve ögrenci görüşleri. Pamukkale Üniversitesi Eğitim Bilimleri Enstitüsü, Denizli.

Yüksel, A. (2010). Okuma güçlüğü çeken bir öğrencinin okuma becerisinin geliştirilmesine yönelik bir çalışma. Kuramsal Ĕgitimbilim Dergisi, 3(1), 124-134. 